\title{
The choice of treatment for myocardial infarction based on individual cardiovascular risk and symptoms of coronary heart disease
}

\author{
M. A. Buleshov ${ }^{1}$, D. M. Buleshov' ${ }^{2}$, Zh. A. Yermakhanova ${ }^{1}$, T. B. Dauitov ${ }^{1}$, S. N. Alipbekova ${ }^{1}$, S. A. Tuktibayeva ${ }^{1}$, \\ A. M. Buleshova ${ }^{1}$
}

\begin{abstract}
According to the data of hospital mortality of patients of the Shymkent cardiological center, the most frequent case of the indicator at the stationary stage in patients with myocardial infarction occurs when the class of acute heart failure according to Killip II-IV is determined in patients, the level of blood glucose is more than $8.0 \mathrm{mmol} / \mathrm{l}$, the level of blood creatinine is more than $123.8 \mathrm{mmol} / \mathrm{l}$ and the absence of arterial hypertension when entering the clinic. The main causes of mortality among such elderly and senile patients were Killip class II-IV, blood glucose level of more than $7.30 \mathrm{mmol} / \mathrm{I}$ blood creatinine level of more than $141.4 \mathrm{mmol} / \mathrm{l}$, belonging to the female sex and the absence of hypertension on admission. Implementation of coronary artery stenting taking into account risk factors affecting mortality in hospital in patients with acute myocardial infarction leads to a decrease in hospital mortality and long-term mortality, compared with conservative treatment. Implantation of drug-coated stents and uncoated metal stents equally reduced the mortality rate of myocardial infarction in patients. In elderly and senile patients with myocardial infarction in combination with diabetes mellitus after coronary artery stenting there is a deterioration in long-term survival. Long-term survival at the end of $2010-2018$ was $83.67 \%$, while in patients with concomitant diabetes mellitus - only $40.03 \%, p=0.045$ (Log-rank test). Thrombolytic therapy did not improve survival in hospital and long-term patients in the elderly and senile age group. Implementation of thrombolysis in elderly and senile patients hospitalized up to 1.5 hours from the onset of symptoms of myocardial infarct, leads to an unreliable reduction in mortality $(p=0.085)$, hospitalized later than 1.5 hours - there is an increase in mortality compared with patients without thrombolysis $(p=0.848)$. Coronary stenting in acute myocardial infarction reduced mortality in elderly and senile patients regardless of the time between the onset of symptoms of myocardial infarction and hospitalization $(p=0.486$ and $p=0.004)$
\end{abstract}

Keywords: myocardial infarction, coronary vessels, thrombosis, thrombolytic therapy, stenting, mortality, main risk factors, mortality reduction

\section{INTRODUCTION}

Innovative methods of cardiac treatment, including prehospital thrombolytic therapy, stenting and coronary artery bypass grafting is one of the most important sections of modern medical science, as cardiovascular disease (CVD), and, in particular, coronary heart disease (CHD) are the main cause of death, as well as the main reason for limiting the social acivity of patients, the growth of psychological depression and a sharp decrease in the financial capacity of this social group. According to medical statistics, more than 100,000 people die annually from cardiovascular diseases in Kazakhstan $(1,2)$. At the same time, the main proportion of emergency hospitalized patients with cardiovascular diseases are patients with acute coronary syndrome (ACS) and acute myocardial infarction (AMI) $(3,4)$.

The study of the reported statistical data of the cardiological service of the city of Shymkent, compiled for 2009-2018 years show that coronary heart disease is most common in the middle, elderly and senile age (5). The case of cardiovascular disease is often seen over the age of 65, and the highest rates are found in men aged 60-70 years (6). At the same time, women have the highest morbidity rate for 75 years. In recent years, there has been a sharp increase in the proportion of elderly and senile patients among patients with coronary heart disease $(8,9)$. During the study years, the growth of specific weight of persons of elderly and senile age in the city of Shymkent (from 9 to 12.7\%) and the

\footnotetext{
1 International Kazakh-Turkish University by named H.A. Yasavi, Turkistan, Kazakhstan.

2 City Cardiological Center, Shymkent, Kazakhstan

Correspondence: M. A. Buleshov

International Kazakh-Turkish University by named H.A. Yasavi, Turkistan, Kazakhstan.
}

Received: 26 Aug 2019, Accepted: 19 Nov 2019

(C) 2019 by the authors; licensee Modestum Ltd., UK. This article is an open access article distributed under the terms and conditions of the Creative Commons Attribution License (http://creativecommons.org/licenses/by/4.0/). 
Turkestan region (7.0-10.5\%) increases the need for strengthening the prevention of age-related diseases and monitoring the health status of the elderly population (10) associated with coronary artery disease.

Currently, there are many innovative methods of treatment of $\mathrm{AMI}$, each of which has certain indications and contraindications for use. It should be noted that the method of early or prehospital expansion of the coronary artery by pharmacological myocardial revascularization or interventional interventions $(11,12)$ is most often used for the treatment of patients with AMI. Endovideo diagnostics and cardiac surgery treatment is currently a rapidly developing method of modern high-tech medicine in Kazakhstan and in particular in the large metropolis of Shymkent. The results of the application of this methodological approach in Shymkent city cardiology center for 2009-2018 years showed that it is an effective method of helping patients with acute coronary syndrome (13). The introduction of endovideosurgical methods in the cardiology center led to a significant decrease in the level of inpatient mortality (from $12.8 \%$ in 2009 to $3.1 \%$ in 2018) and an increase in the survival rate of patients with acute myocardial infarction in middle of $8.7 \pm 0.4$ years in all age groups (14.15).

The vast majority of patients (84.4\%) in need of myocardial revascularization are elderly and senile people. The effectiveness of the use of coronary stents in the acute period of myocardial infarction has been proven in complex studies. At the same time, hospital mortality in stenting of coronary arteries in patients with acute myocardial infarction of elderly and senile age in comparison with drug therapy in real clinical practice has not been studied enough. This circumstance served as the basis for this work.

\section{PURPOSE OF RESEARCH}

To assess the level of hospital mortality in patients subjected to coronary stenting in the acute period of myocardial infarction in elderly and senile patients in comparison with patients receiving thrombolytic therapy or conservative treatment.

\section{MATERIALS AND METHODS}

A complex nonselective clinical and statistical retrospective study was carried out. The medical history of 1269 patients with AMI of middle, elderly and senile age treated in the "Shymkent city cardiology center" in the period from 2009 to 2018 (over 10 years), including 784 men (61.78\%) and 485 women (38.22\%), aged 24 to 94 years, was analyzed. Take into account the following indicators: patients date of myocardial infarction, gender, age, the presence, quantity and character of performed coronary stenting or thrombolytic therapy, also differentiability ECG-type AMI with Q and without Q, KILLIP class, with ST-segment elevation on the ECG, the duration of time from onset of symptoms until the hospitalization, the value of the ejection fraction of the left ventricle, localizing $\mathrm{Ml}$ in the electrocardiogram, the presence or absence of diabetes, renal dysfunction, arterial hypertension, the results of treatment and clinical examination of previous myocardial infarction, laboratory data of the maximum value of troponin levels, glucose, creatinine, hemoglobin, date and cause of death in hospital or in the long period. 698 patients of this register after discharge from the hospital were observed in the city polyclinics of Shymkent, where it was monitored the information about the events that occurred with patients after discharge from the hospital, including the date and cause of death, cases of heart attack, stroke in the remote period (up to 10 years). These data were taken into account in the analysis of long-term survival. The final clinical diagnosis of acute myocardial infarction, based on indicators recommended by the World health organization, was taken for inclusion in the register. These included chest pain for more than 20 minutes, organic changes in the electrocardiogram, increase and subsequent decrease in blood specific cardiac parameters (troponin $\mathrm{T}$ and I). The exclusion criteria were patients from the register of malignant neoplasm, end-stage chronic renal failure, acute cerebrovascular accident in the previous 3 months, unstable angina, patients with coronary artery bypass grafting. According to the classification of the World health organization, all patients were divided by age into 3 groups: patients of middle age (up to 59 years), elderly patients (60-74 years), and senile age (75 years and older). Coronary artery stenting was performed in 386 patients with AMI (30.4\%) (main group), drug treatment was performed in 883 patients $(69.6 \%$, control group). Drug-coated stents were implanted in 184 patients (47.6\%). The state of health of patients after coronary stenting and patients receiving medical therapy was analyzed according to the structure of concomitant pathology in each age group. The statistical difference between the main and control groups in the structure of concomitant pathology was insignificant, which indicates their comparability for analysis. To assess the effect of thrombolytic therapy on hospital mortality, patients with St-segment elevation myocardial infarction (STEMI) who did not undergo percutaneous intervention ( $\mathrm{PCl}-496$ patients) were selected and divided into two groups - with thrombolytic therapy 
Table 1: Assessment of the impact of socio-hygienic and medico - organizational risk factors on prehospital mortality in elderly and senile patients after acute myocardial infarction

\begin{tabular}{|c|c|c|c|c|c|c|c|c|}
\hline \multirow[b]{2}{*}{ Risk factors for hospital mortality } & \multicolumn{2}{|c|}{ Elderly age } & \multicolumn{2}{|c|}{ Confidential interval } & \multicolumn{2}{|c|}{ Senile age } & \multicolumn{2}{|c|}{ Confidential interval } \\
\hline & $\begin{array}{l}\text { The level of } \\
\text { pre-hospital } \\
\text { mortality }\end{array}$ & OR & $\begin{array}{l}\text { Upper } \\
\text { border }\end{array}$ & $\begin{array}{l}\text { Lower } \\
\text { border }\end{array}$ & $\begin{array}{l}\text { The level of } \\
\text { pre-hospital } \\
\text { mortality }\end{array}$ & OR & $\begin{array}{l}\text { Upper } \\
\text { border }\end{array}$ & $\begin{array}{l}\text { Lower } \\
\text { border }\end{array}$ \\
\hline \multicolumn{9}{|c|}{ Medical and organizational risk factors for development of pre-hospital mortality } \\
\hline Later appeal for emergency medical care & 12,82 & 3,84 & 5,03 & 2,65 & 22,58 & 9,82 & 11,16 & 8,48 \\
\hline $\begin{array}{l}\text { Delivery of emergency medical care to the hospital over } 1.5 \\
\text { hours from the onset of symptoms of myocardial infarction }\end{array}$ & 13,7 & 4,52 & 6,45 & 2,91 & 23,34 & 10,46 & 11,88 & 9,04 \\
\hline $\begin{array}{l}\text { Start thrombolytic therapy later than } 1.5 \text { hours from the onset } \\
\text { of symptoms of } \mathrm{Ml} \text {. }\end{array}$ & 15,33 & 6,51 & 7,62 & 5,40 & 26,44 & 12,03 & 13,97 & 10,09 \\
\hline $\begin{array}{l}\text { Start thrombolytic therapy up to } 1.5 \text { hours from the onset of } \\
\text { symptoms of MI. }\end{array}$ & 2,31 & 1,62 & 2,48 & 0,76 & & & & \\
\hline On the dispensary account of a cardiologist is not & 13,92 & 4,41 & 5,02 & 3,80 & 15,67 & 5,42 & 6,26 & 4,58 \\
\hline Does not check your blood pressure & 12,18 & 1,37 & 3,19 & $-0,5$ & 12,89 & 2,64 & 4,61 & 0,67 \\
\hline \multicolumn{9}{|c|}{ Social-hygienic risk factors of pre-hospital mortality } \\
\hline Eating fatty foods & 12,62 & 4,78 & 6,52 & 3,04 & 14,26 & 7,51 & 8,76 & 6,26 \\
\hline Frequent consumption of confectionery products & 4,62 & 1,68 & 2,96 & 0,40 & 6,58 & 4,21 & 5,62 & 2,80 \\
\hline Smoking & 11,51 & 2,37 & 3,56 & 1,18 & 12,94 & 3,97 & 5,01 & 2,93 \\
\hline The use of alcoholic beverages & 12,64 & 3,58 & 4,62 & 2,54 & 13,87 & 4,64 & 6,12 & 2,98 \\
\hline Hypodynamia & 13,67 & 4,92 & 6,16 & 3,68 & 15,74 & 5,83 & 7,24 & 4,42 \\
\hline Obesity & 14,46 & 6,94 & 8,02 & 5,86 & 16,28 & 8,11 & 9,54 & 6,68 \\
\hline Lack of information about myocardial infarction & 10,89 & 2,01 & 3,98 & 0,04 & 12,54 & 3,11 & 4,86 & 1,36 \\
\hline Adverse living conditions & 11,94 & 4,64 & 6,58 & 2,52 & 12,02 & 5,02 & 6,18 & 3,86 \\
\hline Adverse environmental conditions in residential areas & 6,54 & 3,96 & 4,62 & 3,30 & 7,14 & 5,29 & 6,39 & 4,19 \\
\hline Low socio-economic and financial situation & 14,52 & 5,11 & 6,42 & 3,38 & 16,72 & 6,21 & 7,62 & 4,80 \\
\hline
\end{tabular}

(TLT), consisting of 139 patients and without TLT, including 357 patients. We determined the socio-hygienic characteristics in the group of patients with $\mathrm{MI}$ who received $\mathrm{PCl}$ with the installation of a coronary stent. The mean age of these patients was $54.5 \pm 9.9$ years, including: under 60 years - 273 patients, mean age $49.5 \pm 6.5$ years, $60-74$ years 103 patients, mean age $65.5 \pm 4.1$ years, 75 years and older -10 patients, mean age $76.7 \pm 1.8$ years. Among patients with MI receiving thrombolytic therapy, the mean age was $65.5 \pm 11.9$ years, including: up to 60 years -285 people (mean age $51.5 \pm 6.5$ years), $60-75$ years - 363 people (mean age $67.4 \pm 4.2$ years). 75 years and older -235 patients (mean age $79.5 \pm 3.5$ years). Patients of the registry at each stage of treatment received standard drug therapy for patients with AMI. At the same time, at the prehospital stage, they took aspirin, morphine, nitrates, beta-blockers, symptomatic treatment. The hospital continued to take aspirin, ACE inhibitors, beta-blockers, statins, nitrates, heparin, symptomatic treatment, as well as symptomatic therapy aimed at the treatment of comorbidities. Patients who underwent $\mathrm{PCl}$ received double thrombolytic therapy, which included a combination of aspirin and clopidogrel, were hydrated with a physiological solution of sodium chloride. Medical and statistical processing of the results was carried out using statistical software packages BIOSTAT and XLSTAT 2012. Comparison of the obtained arithmetic means with the standard deviation was carried out using $(t)$ - Student's criterion is used for independent samples. Correlation analysis of the degree of correlation between factors and diseases in the form of quantitative characteristics was performed by Pearson with the calculation of the correlation coefficient $(\mathrm{g})$. The relative values are presented as a percentage of observations to the total number of sample statistical aggregates. Multivariate logistic regression analysis was used to identify significant risk factors that have a significant impact on hospital mortality. The quality of the model was determined by ROC-analysis. During which the level of the area indicator under the AUC (Area Under Curve) was estimated. The criterion of "Maximum total sensitivity and specificity" was used to determine the most appropriate cut-off threshold. A comparative evaluation of discrete quantities occurring in independent groups is carried out using the Pearson criterion for the frequency table $2 \times 2$ with the introduction of the continuity correction (by Yeats), as well as the Fisher $z$-criterion and point criterion. The odds ratio (relative risk) and confidence interval were used to compare mortality rates in the two compared groups. Qualitative assessment of long-term survival was carried out using Cox regression model and Kaplan-Mayer method. Log-rank test was used to assess the significance of differences between survival curves. For all the analyses the differences were considered to be significant at the bilateral significance level $p<0.05$. 
Table 2: Hospital mortality rate and relative risk of mortality in patients with myocardial infarction who received and did not receive TLT depending on the age of patients

\begin{tabular}{|c|c|c|c|c|c|c|c|c|c|c|}
\hline \multirow[b]{2}{*}{ Age -group } & \multicolumn{3}{|c|}{ Did not receive thrombolytic therapy } & \multicolumn{3}{|c|}{ Received thrombolytic therapy } & \multirow[b]{2}{*}{ OR } & \multicolumn{2}{|c|}{ Confidence interval } & \multirow{2}{*}{$\begin{array}{c}\text { p, } x- \\
\text { square }\end{array}$} \\
\hline & $\begin{array}{c}\text { Number of } \\
\text { patients }\end{array}$ & Died & $\begin{array}{l}\text { Inpatient } \\
\text { mortality }\end{array}$ & $\begin{array}{c}\text { Number of } \\
\text { patients }\end{array}$ & Died & $\begin{array}{l}\text { Inpatient } \\
\text { mortality }\end{array}$ & & Upper border & Lower border & \\
\hline Middle age & 108 & 4 & 3,57 & 122 & 2 & 1,62 & 0,44 & 2,14 & $-1,26$ & 0,323 \\
\hline Elderly age & 144 & 16 & 11,11 & 53 & 2 & 3,77 & 2,94 & 4,44 & 1,44 & 0,395 \\
\hline Senile age & 104 & 36 & 34,61 & 27 & 3 & 11,11 & 3,11 & 4,34 & 1,88 & 0,192 \\
\hline
\end{tabular}

Table 3: Relative mortality risk and inpatient mortality in elderly and senile patients hospitalized before and after 1.5 hours of onset of symptoms, received and not received TLT

\begin{tabular}{|c|c|c|c|c|c|c|c|c|c|c|}
\hline \multirow{2}{*}{$\begin{array}{c}\text { Patients who } \\
\text { received and did } \\
\text { not receive TLT }\end{array}$} & \multicolumn{3}{|c|}{ Less than 1.5 hours } & \multicolumn{3}{|c|}{$>1,5$ hours } & \multirow[b]{2}{*}{ OR } & \multicolumn{2}{|c|}{ Confidence interval } & \multirow[b]{2}{*}{$\begin{array}{c}\text { p, x- } \\
\text { square }\end{array}$} \\
\hline & $\begin{array}{c}\text { Number of } \\
\text { patients }\end{array}$ & Died & $\begin{array}{l}\text { Inpatient } \\
\text { mortality }\end{array}$ & $\begin{array}{c}\text { Number of } \\
\text { patients }\end{array}$ & Died & $\begin{array}{l}\text { Inpatient } \\
\text { mortality }\end{array}$ & & Upper border & Lower border & \\
\hline $\begin{array}{c}\text { Did not receive } \\
\text { TLT }\end{array}$ & 69 & 11 & 15,94 & 427 & 72 & 16,86 & 2,52 & 3,19 & 1,85 & 0,486 \\
\hline Received TLT & 62 & 2 & 3,22 & 89 & 9 & 10,11 & 3,13 & 4,67 & 1,59 & 0,004 \\
\hline
\end{tabular}

Table 4: The Relative chance of survival of middle-aged patients who had a heart attack, depending on the complex treatment (thrombolytic therapy and stenting of coronary vessels)

\begin{tabular}{|c|c|c|c|c|c|c|c|c|}
\hline \multirow[t]{3}{*}{ A risk factor for inpatient mortality } & \multicolumn{2}{|c|}{$\begin{array}{c}\text { Received comprehensive } \\
\text { treatment and vascular } \\
\text { stenting }\end{array}$} & \multicolumn{2}{|c|}{ No stents were } & \multicolumn{4}{|c|}{$\begin{array}{l}\text { Reliability of indicators of efficiency of complex treatment } \\
\text { and stenting of coronary vessels of infarct patients }\end{array}$} \\
\hline & \multirow{2}{*}{$\begin{array}{c}\text { Number of } \\
\text { patients }\end{array}$} & \multirow{2}{*}{$\begin{array}{l}\text { Died in } \\
\text { hospital }\end{array}$} & \multirow{2}{*}{$\begin{array}{c}\text { Number of } \\
\text { patients }\end{array}$} & \multirow{2}{*}{$\begin{array}{l}\text { Died in } \\
\text { hospital }\end{array}$} & \multirow{2}{*}{$\begin{array}{l}\text { Odds ratio } \\
\text {-ROS- }\end{array}$} & \multicolumn{2}{|c|}{ Confidence interval } & \multirow{2}{*}{$\mathbf{P}$} \\
\hline & & & & & & Upper border & Lower border & \\
\hline Proportion of men & 457 & 3 & 99 & 7 & 10,77 & 12,12 & 9.42 & $<0,05$ \\
\hline $\begin{array}{l}\text { Hypertension installed at receipt in } \\
\text { hospital }\end{array}$ & 405 & 3 & 93 & 7 & 10,90 & 12,26 & 9,54 & $<0,05$ \\
\hline Diabetes & 71 & 1 & 42 & 4 & 7,36 & 9,88 & 4,84 & $<0,05$ \\
\hline Acute myocardial infarction & 304 & 2 & 152 & 7 & 2,89 & 4,46 & 1,32 & $<0,05$ \\
\hline $\begin{array}{l}\text { Myocardial infarction with ST wave } \\
\text { elevation }\end{array}$ & 359 & 2 & 103 & 9 & 17,10 & 17,15 & 16,85 & $<0,05$ \\
\hline History of myocardial infarction & 103 & 2 & 79 & 4 & 2,69 & 4,41 & 0,97 & $>0,05$ \\
\hline Front localization & 291 & 1 & 87 & 3 & 10,35 & 15,25 & 5,45 & $<0,05$ \\
\hline Chronic kidney disease & 42 & 1 & 94 & 11 & 5,43 & 6,48 & 4,38 & $<0,05$ \\
\hline KILLIP II - IV & 53 & 3 & 67 & 8 & 2,26 & 2,96 & 1,56 & $<0,05$ \\
\hline The level of ejection fraction $<40 \%$ & 44 & 2 & 56 & 7 & 3,0 & 3,98 & 2,02 & $<0,05$ \\
\hline The proportion of patients with $\mathrm{PCl}$ & $272(48,92 \%)$ & 2 & 284 & 6 & 2,91 & 4,51 & 1,31 & $<0,05$ \\
\hline $\begin{array}{l}\text { Proportion of patients with thrombolytic } \\
\text { therapy }\end{array}$ & $248(26,6 \%)$ & 1 & 408 & 17 & 2,65 & 3,74 & 1,56 & $<0,05$ \\
\hline
\end{tabular}

\section{RESULTS}

The analysis of in-hospital mortality in patients with thrombolytic therapy (TLT), and non-TLT group STEMI in different age groups (Table 1). TLT significantly reduced the level of hospital mortality in middle-aged patients. This conclusion is confirmed by the fact that the odds ratio is less than 1 and the upper limit of the confidence interval is higher, and the lower limit is less than $1(\mathrm{OR}=0.44, \mathrm{Cl}=2.14$ and $-1.26, p=0.323)$. These indicators show that there is no statistical significance of the relationship between thrombolytic therapy and a decrease in the level of hospital mortality in middleaged patients $(p=0.323)$. At the same time, there was a tendency to increase by 1.5 times the mortality of elderly patients with STEMI (OR=2,94, $\mathrm{Cl}=4,44-1,44, \mathrm{p}=0,395)$ and senile age $(\mathrm{OR}=3,11, \mathrm{Cl}=4,34-1,88, \mathrm{p}=0,192)$ who received TLT. It is known that the duration of the time delay from the onset of $\mathrm{Ml}$ symptoms to pharmacological reperfusion is an important factor affecting hospital mortality.

In this regard, the analysis of the effect of time delay on hospital mortality in patients receiving TLT.

The method of ROC-analysis revealed a linear correlation between the time from the pain attack before the start of pharmacological reperfusion and hospital mortality of elderly patients $(\mathrm{OR}=2,52, \mathrm{Cl}=3,19-1.85, p=0,486)$ and senile(OR=3,13, $\mathrm{Cl}=4.67-1,59, \mathrm{p}=0.004)$ of age.

The cutoff value was found in time from the onset of Ml symptoms to the moment of hospitalization, dividing patients into categories of low and high risk of hospital mortality -1.5 hours from pain to hospitalization. 
Table 5: Comparative evaluation of the effectiveness of stenting of coronary vessels in patients with elderly myocardial infarction

\begin{tabular}{|c|c|c|c|c|c|c|c|c|}
\hline \multirow{3}{*}{$\begin{array}{l}\text { A risk factor for inpatient mortality } \\
\text { Proportion of men }\end{array}$} & \multicolumn{2}{|c|}{$\begin{array}{c}\text { Received comprehensive } \\
\text { treatment and vascular } \\
\text { stenting }\end{array}$} & \multicolumn{2}{|c|}{ No stents were } & \multicolumn{4}{|c|}{$\begin{array}{l}\text { Reliability of indicators of efficiency of complex treatment } \\
\text { and stenting of coronary vessels of infarct patients }\end{array}$} \\
\hline & \multirow{2}{*}{$\begin{array}{c}\begin{array}{c}\text { Number of } \\
\text { patients }\end{array} \\
194 \\
\end{array}$} & \multirow{2}{*}{$\begin{array}{c}\begin{array}{c}\text { Died in } \\
\text { hospital }\end{array} \\
3\end{array}$} & \multirow{2}{*}{$\begin{array}{c}\begin{array}{c}\text { Number of } \\
\text { patients }\end{array} \\
57 \\
\end{array}$} & \multirow{2}{*}{$\begin{array}{c}\begin{array}{c}\text { Died in } \\
\text { hospital }\end{array} \\
4\end{array}$} & \multirow{2}{*}{$\begin{array}{c}\begin{array}{c}\text { Odds ratio } \\
\text {-ROS- }\end{array} \\
2,05\end{array}$} & \multicolumn{2}{|c|}{$\frac{\text { Confidence interval }}{\text { Upper border Lower border }}$} & \multirow{2}{*}{\begin{tabular}{c|}
$P$ \\
$>0,05$ \\
\end{tabular}} \\
\hline & & & & & & 3,57 & 0,53 & \\
\hline $\begin{array}{l}\text { Hypertension installed at receipt in } \\
\text { hospital }\end{array}$ & 398 & 6 & 69 & 4 & 4,02 & 5,29 & 2.75 & $<0,05$ \\
\hline Diabetes & 89 & 5 & 16 & 3 & 3,87 & 5,40 & 2,34 & $<0,05$ \\
\hline Acute myocardial infarction & 127 & 6 & 74 & 5 & 1,46 & 2,65 & 0,27 & $>0,05$ \\
\hline $\begin{array}{l}\text { Myocardial infarction with ST wave } \\
\text { elevation }\end{array}$ & 209 & 4 & 54 & 3 & 3,01 & 4,53 & 1,49 & $<0,05$ \\
\hline History of myocardial infarction & 122 & 4 & 23 & 3 & 4,42 & 5,98 & 2,86 & $<0,05$ \\
\hline Front localization & 192 & 3 & 141 & 4 & 1,84 & 3,32 & 0,36 & $>0,05$ \\
\hline Chronic kidney disease & 107 & 5 & 35 & 4 & 2,63 & 3.98 & 1,28 & $<0,05$ \\
\hline KILLIP II - IV & 82 & 4 & 53 & 7 & 2,97 & 4,22 & 1,40 & $<0,05$ \\
\hline The level of ejection fraction $<40 \%$ & 39 & 5 & 24 & 5 & 1,79 & 3,14 & 0,44 & $>0,05$ \\
\hline The proportion of patients with $\mathrm{PCl}$ & 73 & 1 & 29 & 2 & 5,33 & 7,73 & 2,87 & $<0,05$ \\
\hline $\begin{array}{l}\text { Proportion of patients with thrombolytic } \\
\text { therapy }\end{array}$ & 62 & 3 & 16 & 3 & 4,54 & 6,22 & 2,68 & $<0,05$ \\
\hline
\end{tabular}

In accordance with this, the analysis of hospital mortality of elderly and senile patients hospitalized before and after 1.5 hours from the onset of symptoms of MI, received and not received TLT (Table 2). $t$ was found that hospitalization later than 1.5 hours from the onset of Ml symptoms, followed by thrombolytic therapy in elderly and senile patients was associated with higher mortality relative to patients who did not have thrombolysis ( $26.02 \%$ versus $12.32 \%, p=0.004$, $z-$ criterion).

The analysis of the hospital mortality of middle-aged patients depending on the time delay revealed that the later thrombolytic therapy (more than 1.5 hours from the development of symptoms of $\mathrm{MI}$ ) is associated with a higher mortality relative to the thrombolysis performed earlier ( $p=0.000, z$-criterion). In the group of patients without TLT, such a pattern was not observed, $\mathrm{p}=0.179$ (z-criterion). At the same time, the difference in mortality of middle-aged patients hospitalized later than 1.5 hours from the onset of Ml symptoms in the groups of patients with and without thrombolytic therapy was not revealed, $p=0.546$, $z$-criterion.

The results of the analysis of the effect of time factor on hospital mortality in elderly and senile patients after TLT were compared with similar indicators in patients who underwent $\mathrm{PCl}$.

Numerous comprehensive studies have shown that the features of the clinical course of myocardial infarction in the elderly and senile age compared with patients of middle age are: a higher incidence of concomitant hypertension, diabetes, post infarction cardiosclerosis, chronic kidney disease, a relatively severe course of myocardial infarction, manifested by an increase in the frequency of KILLIP II-IV, EF $<40 \%$, a decrease in the proportion of patients with Q-MI and myocardial infarction with St-segment elevation (STEMI), as well as a significant increase in hospital mortality with age. Application of the method of logistic regression using the technique of "Reverse step-by-step analysis" revealed that a significant influence on the mortality of patients Ml elderly in hospital (adjusted for the influence of other important factors), was provided by the KILLIP class $(p=0.001, O R=2.1(95 \% \mathrm{Cl}=1.2-3.7))$, the blood glucose level $(p<0.0001, \mathrm{OR}=$ $1.2(95 \% \mathrm{Cl}=1.05-1,3)$, the level of blood creatinine $(p<0.0001, \mathrm{OR}=2.7(95 \% \mathrm{Cl}=1.1-6.3)$, the lack of hypertension $(p=0.009, O R=3.0(95 \% \mathrm{Cl}=0.7-13.2)$.

The risk of hospital mortality was determined by ROC-analysis: KILLIP II class, blood glucose level $8.0 \mathrm{mmol} / \mathrm{l}$, blood creatinine level $123.8 \mathrm{mmol} / \mathrm{l}$.

The method of logistic regression based on the definition of border values for quantitative factors by the method of ROC analysis determined that a significant impact on the mortality of patients with myocardial infarction elderly in hospital (adjusted for the influence of other important factors) are belonging to the female sex $(p=0.018, O R=3,9(95 \%$ $\mathrm{Cl}=1,3-12,3)$, KILLIP class $(\mathrm{p}=0.001, \mathrm{OR}=2,1(95 \% \mathrm{Cl}=1,4-3,4)$, the value of the edge $-\mathrm{II}$, the blood glucose level $(p=0.002, O R=1,2(95 \% \mathrm{Cl}=1,04-1,4)$, the edge value was $7.3 \mathrm{mmol} / \mathrm{l})$, the level of blood creatinine $(p=0.002, O R=4,1$ (95\% Cl=1,7 - 9.9), boundary value $-141.4 \mu \mathrm{mol} / \mathrm{l}$ and absence of $\mathrm{AH}(\mathrm{p}=0.0001, \mathrm{OR}=6.0(95 \% \mathrm{Cl}=2.2-16.4)$ ).

The results of the study using the Log - rank test showed that in all age groups, stenting of coronary vessels leads to a significant reduction in hospital mortality (Figures 4-6). In the main group of patients with Ml, belonging to the middle age group, there was an unreliable decrease in mortality compared to the control group. For middle-aged patients, there 
Table 6: Comparative evaluation of the effectiveness of coronary vessels stenting in patients with myocardial infarction of senile age

\begin{tabular}{|c|c|c|c|c|c|c|c|c|}
\hline \multirow{3}{*}{$\begin{array}{l}\text { A risk factor for inpatient mortality } \\
\text { Proportion of men }\end{array}$} & \multicolumn{2}{|c|}{$\begin{array}{c}\text { Received comprehensive } \\
\text { treatment and vascular } \\
\text { stenting }\end{array}$} & \multicolumn{2}{|c|}{ No stents were } & \multicolumn{4}{|c|}{$\begin{array}{l}\text { Reliability of indicators of efficiency of complex treatment } \\
\text { and stenting of coronary vessels of infarct patients }\end{array}$} \\
\hline & \multirow{2}{*}{$\begin{array}{c}\text { Number of } \\
\text { patients } \\
59\end{array}$} & \multirow{2}{*}{$\begin{array}{c}\begin{array}{c}\text { Died in } \\
\text { hospital }\end{array} \\
4\end{array}$} & $\begin{array}{c}\text { Number of } \\
\text { patients }\end{array}$ & $\begin{array}{l}\text { Died in } \\
\text { hospital }\end{array}$ & $\begin{array}{l}\text { Odds ratio } \\
\text {-ROS- }\end{array}$ & \multicolumn{2}{|c|}{$\frac{\text { Confidence interval }}{\text { Upper border Lower border }}$} & $\mathbf{P}$ \\
\hline & & & 16 & 3 & 3,17 & 4,78 & 1,56 & $<0,05$ \\
\hline $\begin{array}{l}\text { Hypertension installed at receipt in } \\
\text { hospital }\end{array}$ & 213 & 4 & 31 & 4 & 7,74 & 9,18 & 6,30 & $<0,05$ \\
\hline Diabetes & 45 & 3 & 9 & 3 & 7,0 & 8,80 & 5,20 & $<0,05$ \\
\hline Acute myocardial infarction & 89 & 4 & 16 & 3 & 4,90 & 6,49 & 3,31 & $<0,05$ \\
\hline $\begin{array}{l}\text { Myocardial infarction with ST wave } \\
\text { elevation }\end{array}$ & 79 & 3 & 55 & 6 & 4,41 & 4,51 & 1,69 & $<0,05$ \\
\hline History of myocardial infarction & 62 & 4 & 21 & 4 & 3,41 & 4,90 & 1,92 & $<0,05$ \\
\hline Front localization & 108 & 5 & 26 & 4 & 3,74 & 6,10 & 1,38 & $<0,05$ \\
\hline Chronic kidney disease & 76 & 6 & 37 & 5 & 1,82 & 3,07 & 0,57 & $>0,05$ \\
\hline KILLIP II - IV & 69 & 4 & 49 & 8 & 3,17 & 4,42 & 1,92 & $<0,05$ \\
\hline The level of ejection fraction $<40 \%$ & 29 & 4 & 23 & 6 & 2,20 & 3,59 & 0,81 & $>0,05$ \\
\hline The proportion of patients with $\mathrm{PCl}$ & 27 & 3 & 48 & 9 & 1,85 & 3,22 & 0,48 & $>0,05$ \\
\hline $\begin{array}{l}\text { Proportion of patients with thrombolytic } \\
\text { therapy }\end{array}$ & 20 & 3 & 16 & 4 & 1,89 & 3,54 & 0,24 & $>0,05$ \\
\hline
\end{tabular}

Table 7: The level of hospital mortality of patients who received and did not receive stenting of coronary vessels

\begin{tabular}{|c|c|c|c|c|c|c|c|c|c|c|c|}
\hline \multirow{2}{*}{ Comparison group } & \multicolumn{3}{|c|}{ Middle age, $\mathrm{n}=556$} & \multirow[b]{2}{*}{$\mathbf{P}$} & \multicolumn{3}{|c|}{ Elderly age, $n=467$} & \multirow[b]{2}{*}{$\mathbf{P}$} & \multicolumn{3}{|c|}{ Senile age,n = 244} \\
\hline & $\begin{array}{l}\text { Absolute } \\
\text { number }\end{array}$ & $\begin{array}{c}\text { Number of } \\
\text { deaths }\end{array}$ & $\begin{array}{c}\text { Inpatient } \\
\text { mortality, \% }\end{array}$ & & $\begin{array}{c}\text { Absolute } \\
\text { number }\end{array}$ & $\begin{array}{c}\text { Number of } \\
\text { deaths }\end{array}$ & $\begin{array}{c}\text { Inpatient } \\
\text { mortality, \% }\end{array}$ & & $\begin{array}{l}\text { Absolute } \\
\text { number }\end{array}$ & $\begin{array}{c}\text { Number of } \\
\text { deaths }\end{array}$ & $\begin{array}{c}\text { Inpatient } \\
\text { mortality, \% }\end{array}$ \\
\hline Control group & 284 & 8 & 2,82 & 0,000 & 363 & 43 & 11,84 & 0,026 & 235 & 44 & 18,72 \\
\hline Main group & 272 & 2 & 0,74 & 0,717 & 104 & 1 & 0,96 & 0,424 & 9 & 1 & 11,1 \\
\hline p, x-square & & 0,127 & & & & 0,002 & & & & 0,779 & \\
\hline
\end{tabular}

is no statistical significance of the relationship between stenting and inpatient mortality when the patient has a history of post-infarction. For elderly patients, there is no statistical significance between stenting and inpatient mortality in cases where the patient has chronic kidney disease, the ejection fraction level $<40 \%$, the patient has acute myocardial infarction.

For elderly patients, the confidence interval in arterial hypertension upon admission to hospital, diabetes, myocardial infarction with elevation wave St KILLIP II-IV, chronic kidney disease includes 1. This means that the statistical significance of the association between risk factor and inpatient mortality is significant.

Among elderly patient's mortality in the main group was $0.96 \%$, in the control group $-11.84 \%(p=0.002)$. Patients of senile age also showed an unreliable decrease in mortality in the study group $(p=0.779)$. Thus, the greatest differences in hospital mortality between the main and control groups were found in elderly patients, $p=0.002(x-s q u a r e)($ Table 6).

In the control group there was an increase in hospital mortality of patients with myocardial infarction with an increase in the age group. Thus, in the middle age the mortality rate was $2.82 \%$, in the elderly $-11.84 \%(p=0.000)$, which is four times higher than the mortality of middle-aged patients; in the senile age $-18.72 \%$, which is 2 times higher compared to the elderly, $p=0.026$.

The correlation coefficient $(\mathrm{g})$ of the level of hospital mortality with age in the control group was $0.997 \mathrm{units}, \mathrm{p}=0.045$.

In contrast to the control group, during coronary stenting there is no significant correlation between hospital mortality of patients with increasing age of patients. So the mortality rate was in the middle age $-0.74 \%$, in the elderly $0.96 \%$, in the senile $-11.1 \% ; p=0.717$ and 0.424 , respectively; differences in mortality rates between the middle and old age $-p=0.205$, the correlation coefficient $g=0.866, p=0.333$. The results can be explained by the relatively low level of inpatient mortality in elderly and senile patients in the percutaneous intervention group ( $\mathrm{PCl})$.

In order to assess the medical effectiveness of coronary stenting in reducing the risk of inpatient mortality of patients with myocardial infarction of elderly and senile age, who had comorbidities, multivariate analysis by logistic regression was performed, taking into account previously identified risk factors independently affecting hospital mortality in elderly and senile patients. The study revealed that stenting of coronary arteries in myocardial infarction in elderly and senile patients has a protective role in relation to hospital mortality in elderly and senile with $\mathrm{Ml}$, taking into account risk factors $(p=0.039, O R=0.1(95 \% \mathrm{Cl}=0.012-0.893)$. 


\section{DISCUSSION}

Encouraging results of coronary stenting before thrombolytic therapy in myocardial infarction were obtained in the results of long-term and dynamic follow-up of patients. Thus, as a result of the ACIP study, which consisted of a twoyear follow-up in the groups of patients with acute myocardial infarction and receiving complex medical treatment, the mortality rate was $6.6 \%$, and in the group of patients who underwent aorta coronary bypass surgery and stenting of the coronary vessels of the myocardium; this figure was $1.1 \%$. In the results of the RITA 2 study $(11,12,15,16)$ the number of deaths from myocardial infarction in the percutaneous intervention group $(\mathrm{PCl})$ was $6.3 \%$, and in the group of complex medical treatment - 3.3\% $(p=0.02)$. In addition, the implementation of percutaneous interventions caused a more significant reduction in symptoms in patients with severe angina. On the other hand, according to reliable data from the time study, long-term survival in patients with stable angina of class II and higher (according to the Canadian classification) at the age of more than 75 years was similar in the groups of $\mathrm{PCl}$ and drug treatment, although in both groups there was a decrease in symptoms of angina and improved quality of life.

The results of the COURAGE study (14), one of the largest of the completed scientific studies to date, showed no significant differences in the frequency of development of the main cardiovascular abnormalities, except that the frequency of angina attacks in the group of invasive treatment in the first years of observation decreased. However, it should be noted that the COURAGE study did not include patients with high risk factors. In view of this circumstance, the possibility of using the results of the COURAGE study on the General population of patients with chronic CHD is very limited (29).

A study of the cardiovascular mortality rate and the probability of survival in the first year after myocardial revascularization showed that the risk of "total mortality" was 3.3\% and the probability of recurrent nonfatal infarction was reduced by $2 \%$. During the study year, it was found that the frequency of hospitalizations significantly decreased, improved clinical manifestations of stable angina pectoris, increased coronary reserve of the heart after revascularization in comparison with standard basic therapy. Echo-cardiographic study showed that after coronary stenting there was a significant increase in the left ventricular ejection fraction at the end of the follow-up period in patients against patients where standard therapy was prescribed.

The results of our study found that thrombolytic therapy does not improve survival in hospital and long-term patients in the older age group. Thrombolysis in elderly and senile patients hospitalized up to 1.5 hours from the onset of symptoms of myocardial infact leads to an unreliable decrease in mortality, and in hospitalized patients later than 1.5 hours leads to a significant increase in mortality compared with patients without thrombolysis. Coronary stenting in acute myocardial infarction significantly reduced mortality in elderly and senile patients regardless of the time between the onset of symptoms of myocardial infarction and hospitalization.

This problem requires further and in-depth development in order to develop a clear clinical assessment, and if the benefit of coronary artery stenting significantly exceeds the risk, patients of elderly and senile age with stable angina can be recommended to use this innovative method. The main arguments that determine the choice of treatment should still be the individual cardiovascular risk of mortality of patients and the severity of symptoms of coronary heart disease $(13,17,19,23)$.

\section{REFERENCES}

1. Buleshov DM, Ermakhanova JA, Buleshov MA. Evaluation of the efficiency of resource provision of cardiology surby on the health status of the population of the Turkestan region. Bulletin of the doctors of the Republic of Kazakhstan, 4:34-42.

2. Buleshov DM. The modern views on the anatomy of the heart and the coronary vessels. The Bulletin of the doctors of the Republic of Kazakhstan, 4:67-71.

3. Yermakhanova ZhA, Buleshov DM, Buleshov MA, Tuktibayeva SA. Resource provision of the cardiological service and population health status of the South Kazakhstan Region. Drug Invention Today, 2018;10(4):3470-4.

4. Grinhal'h T. Fundamentals of Evidence-Based Medicine. Moscow: GEOTAR-Media; Russian (Green-khalkh T Fundamentals of evidence-based medicine). GEOTAR-Media; 2006.

5. Guidelines on the management of stable angina pectoris. The Task Force the management of stable angina pectoris of the European Society of Cardiology Eur Heart J., 2006;27(11):1391-8. https://doi.org/10.1093/eurheartj/ehl001 PMid:16735367 
6. Guidelines on myocardial revascularization. The Task Force on Myocardial Revascularization of the European Society of Cardiology (ESC) and the European Association for Cardio-Thoracic Surgery (EACTS). Eur Heart J, 2010;31:2501-55. https://doi.org/10.1093/eurheartj/ehq277 PMid:20802248

7. Katritsis G, Syontis GC, Kastraty A. Optimal timing of coronary angiography and potential intervention in nonST-elevation acute coronary syndromes. Eur Heart J, 2011;32:32-40. https://doi.org/10.1093/eurheartj/ehq276 PMid:20709722

8. Expert Consensus Document on the use of antiplatelet agents. The Task Force on the use of antiplatelet agents in patients with atherosclerotic cardiovascular disease of the European Society of Cardiology. Eur Heart J, 2004;25:166-81. https://doi.org/10.1016/j.ehj.2003.10.013 PMid:14720534

9. Rebrova OY. Statistical analysis of medical data. Application software package STATISTICA. M.:Media sphere; 2004. English (Rebrova O. Y. Statistical analysis of medical data. Application of the STATISTICA application package. Media sphere; 2004).

10. Chulpanov UYu, Turdalieva BS, Buleshov MA. The main aspects of the introduction of high-tech medical care in the Republic of Kazakhstan. Proceedings of the XV international youth scientific and practical conference, Ekaterinburg, March 28, 2018 "Topical issues of development of modern society of Economics and vocational education". Section IV- 213-219.

11. Pepine $C J$, Bourassa $M G$, Chaitman $B R$, et al. Factors influencing clinical outcomes after revascularization $n$ the asymptomatic cardiac ischemia pilot (ACIP). ACIP Study Group. J Card Surg., 1999;14(1):1-8. https://doi.org/10.1111/j.1540-8191.1999.tb00943.x PMid:10678439

12. Henderson RA, Pocock SJ, Clayton TC, et al. Seven-year outcome in the RITA-2 trial: coronary angioplasty versus medical therapy. J Am. Coll. Cardiol., 2003;42:1161-70. https://doi.org/10.1016/S0735-1097(03)00951-3

13. Physterer M. Trial of Invasive versus Medical therapy in Elderly patients Investigators. Long-term outcome in elderly patients with chronic angina managed invasively versus by optimized medical therapy: four-year followup of the randomized Trial of Invasive versus Medical therapy in Elderly patients (TIME). Circulation 2004;110(10):1213-8. https://doi.org/10.1161/01.CIR.0000140983.69571.BA PMid:15337691

14. Boden WE, O'rourke RA, Teo KK, et al. The evolving pattern of symptomatic coronary artery disease in the United States and Canada: baseline characteristics of the Clinical Outcomes Utilizing Revascularization and Aggressive Drug Evaluation (COURAGE) trial. Am. J Cardiol., 2007;99(2):208-12. https://doi.org/10.1016/j.amjcard.2006.07.082 PMid:17223420

15. Min SY, Park DW, Yun SC. Major predictors of long-term clinical outcomes after coronary revascularization in patients with unprotected left main coronary disease: analysis from the MAIN-COMPARE study. Circ. Cardiovasc. Interv., 2010;3:127-33. https://doi.org/10.1161/CIRCINTERVENTIONS.109.890053 PMid:20407112

16. Long-Term Comparison of Drug-Eluting Stents and Coronary Artery Bypass Grafting for Multivesse Coronary Revascularization: 5-Year Outcomes from the Asan Medical Center-Multivessel Revascu-arization Registry. J Am. Coll. Cardiol., 2011;57:128-37.

17. Conti CR. Unstable angina before and after infarction: thoughts on pathogenesis and therapeutic strategies. Heart Lung, 1986 Jul;15(4):361-8.

18. C. Richard Conti. Ischemic heart disease. Journal of the American College of Cardiology, April 2000;35(5)(Supplement 2). https://doi.org/10.1016/S0735-1097(00)80040-6

19. Arutyunov GP. The Rate of formation of the necrosis focus and the severity of the clinical picture in acute myocardial infarction. Author's thesis for the degree Doc. honey. sciences'. Moscow Honey. Stomat. Inst. by named Semashko, 1994.

20. Panchenko EP, Dobrovolsky AB. Thrombosis in cardiology. Mechanisms of development and possibilities of therapy. Moscow, 1999:308.

21. Ambrose JA, Tannenbllum MA, Alexopouluos $D$, et al. Angiographic progression of coronary artery disease and the development of myocardial infarction. J Am. Col.I Cardiol., 1088-12:56-62. https://doi.org/10.1016/07351097(88)90356-7

22. Fitzgerald LA, Philips DR. Platelet membrane glycoproteins. In Hemostasis and Thrombosis: Basic principles and clinical practice. In RW Colman, J Hirsh, YJ Marder, EW Salzman (Eds.) (2nd ed.). Philadelphia, Pa: JB Lippincott, 1987:572-93. 
23. Gram J, Jespersen J, Kluft C, Rijken DC. On the usefulness of fibrinolysis variables in the characterization of a risk group for myocardial reinfarction. Acta Med. Scand., 1987;221:149-53. https://doi.org/10.1111/j.09546820.1987.tb01259.x PMid:3591453

24. Bokarev IN, Dougalis SA. Thrombolytic therapy of myocardial infarction. BC, 1998;6(3):3-9.

25. The Task Force on the Management of Acute Myocardial Infarction of the European Society of Cardiology. Management of acute myocardial infarction syndromes in patients presenting with St-segment elevation. Eur Heart J, 2003;24:28-66. https://doi.org/10.1016/S0195-668X(02)00618-8

26. White H, Van de Werf F, Thrombolysis for Acute Myocardial Infarction. Circulation, 1998;97:1632-46. https://doi.org/10.1161/01.CIR.97.16.1632 PMid:9593569

27. Yavelov IS. Clinical aspects of thrombolytic therapy in acute myocardial infarction. Farmateka, 2003;6:14-24.

28. Col J, Decoster O, Hanique G. et al. Infusion of heparin conjunct to streptokinase accelerates reperfusion of acute myocardial infarction: results of double-blind randomized study (08IRI8). Circulation, 1992;86:1-259.

29. Proceedings of the plenary session of the Moscow city society of cardiology. Thrombolytics and restoration of coronary blood flow in myocardial infarction. Cardiology, 1997;8:57-67.

30. The International Study Group. In-hospital mortality and clinical course of 20, 891 patients with suspected acute myocardial infarction randomized between alteplase and streptokinase with or without heparin. Lancet, 1990;336:71-5. https://doi.org/10.1016/0140-6736(90)91590-7

31. The GUSTO Investigators. An international randomized trial comparing four thrombolytic strategies for acute myocardial infarction. N.Engl. J.Med., 1993;329:673-82. https://doi.org/10.1056/NEJM199309023291001 PMid:8204123

32. EMERAS (Estudio Mnlticentrico Estreptoquinasa Republicas de America de Sur) Collaborative Group. Randomized trial of late thrombolysis in patients of suspected acute myocardial infarction. Lancet, 1993;342:76772. https://doi.org/10.1016/0140-6736(93)91539-X

33. LATE Study Group. Late Assesment of thrombolytic efficacy (LATE) study with alteplse 6-24 hours after onset of acute myocardial infarction. Lancet, 1993;342:759-66. https://doi.org/10.1016/0140-6736(93)91538-W

34. The GUSTO investigators. An International randomized trial comparing four thrombolytic strategies for acute myocardial infarction. N Engl J Med, 1993;329:673-82. https://doi.org/10.1056/NEJM199309023291001 PMid:8204123

35. Morrison LJ, Verbeek PR, McDonald AC, Sawadsky BV, Cook DJ. Mortality and prehospital thrombolysis for acute myocardial infarction: a meta-analysis. Jama, 2000 May 24;283(20):2686-92. https://doi.org/10.1001/jama.283.20.2686 PMid:10819952

36. Varshavsky SYu, Feldman CX, Zhuravlev KB, Borisov MV, Loginovskaya OA. Thrombolytic therapy in acute myocardial infarction at the prehospital stage. Clinical medicine, 1991;4:38-41.

37. Ketley D, Woods KL. Impact of clinical trials on clinical practice example of thrombolysis for acute myocardial infarction. Lancet, 1993;342:891-4. https://doi.org/10.1016/0140-6736(93)91945-I

38. Golikov AP, Zvereva TB. Immediate and long-term results of thrombolytic therapy in patients with myocardial infarction: the need for differentiated treatment. Cardiology, 1992;32(4):5-10.

39. Topol EJ. Early myocardial reperfusion: an assessment of current strategies arction. Eur Heart J, 1996;17(Suppi E):42-8. https://doi.org/10.1093/eurheartj/17.suppl_E.42 PMid:11824003

40. Conti CR. Unstable angina before and after infarction: thoughts on pathogenesis and therapeutic strategies. Heart Lung, 1986 Jul;15(4):361-8.

41. Maseri A. Pathogenetic mechanism of post-infarction angina. Eur Heart J., 1986 Dec- 7; Suppl:3-5. https://doi.org/10.1093/eurheartj/7.suppl_C.3 PMid:3816826

42. The International Study Group. In-hospital mortality and clinical course of 20,891 patients with suspected acute myocardial infarction randomized between alteplase and streptokinase with or without heparin. Lancet, 1990;336:71-5. https://doi.org/10.1016/0140-6736(90)91590-7

$$
\diamond \diamond \diamond \diamond \diamond \diamond \diamond
$$

